JSIP: Jurnal Studi Ilmu Pemerintahan

Volume 2, No 1 Februari 2021

ISSN: 2722-7405

\title{
KINERJA PEMERINTAH TERHADAP PENGELOLAAN SAMPAH DI KELURAHAN MACORAWALIE KECAMATAN PANCA RIJANG KABUPATEN SIDENRENG RAPPANG
}

\author{
Sapri $^{1}$ \\ Lukman ${ }^{2}$ \\ Citra Darwis 3 \\ Herman Sanusi ${ }^{4}$
}

\begin{abstract}
1,2 Universitas Muhammadiyah Sidenreng Rappang, Indonesia
3Mahasiswa Universitas Muhammadiyah Sidenreng Rappang, Indonesia

${ }^{4}$ Institit Agama Islam Negeri Bone, Indonesia sapritajuddin3@gmail.com
\end{abstract}

Article Info

Keyword:

Kinerja Pemerintah ${ }^{1}$

Pengelolaaan $^{2}$

Sampah $^{3}$

Kata Kunci:

Government

Performance ${ }^{1}$

Management $^{2}$

Waste

\begin{abstract}
The purpose of this study is to determine the effect of Government Performance on Waste Management in Macorawalie Village, Panca Rijang District, Sidenreng Rappang Regency. The population in conducting this research is the community with male and female gender totaling 895 people from 2 hamlets, the data collection technique is the Yount formula with the results of 95 people, taken based on purposive sampling. The type of research used is quantitative descriptive research type, data collection techniques used are observation, questionnaires and interviews. Data analysis technique is using validity, reliability using SPSS 16.0 application and Likert Scale. Based on the results obtained from the questionnaire analysis, a recapitulation of Government Performance variables obtained $67.6 \%$ is included in the "Good" category. Recapitulation of Waste Management variable $64.4 \%$ included in the category of "Good".
\end{abstract}

\begin{abstract}
Abstrak: Tujuan penelitian ini yaitu untuk mengetahui pengaruh Kinerja Pemerintah terhadap Pengelolaan Sampah di Kelurahan Macorawalie Kecamatan Panca Rijang Kabupaten Sidenreng Rappang. Populasi dalam melakukan penelitian ini yaitu masyarakat dengan jenis kelamin laki-laki dan perempuan yang berjumlah 895 jiwa dari 2 dusun, teknik pengumpulan data yaitu rumus Yount dengan hasil 95 orang, diambil berdasarkan purposive sampling. Tipe penelitian yang digunakan yaitu tipe penelitian deskriptif kuantitatif, teknik pengumpulan data yang digunakan yaitu observasi, kuesioner dan wawancara. Teknik analisi bdata yaitu menggunakan uji validitas, reliabilitas dengan menggunakan bantuan aplikasi SPSS 16,0 dan Skala Likert. Dari hasil yang di dapat dari olah kuesiuoner diperoleh rekapitulasi variabel Kinerja Pemerintah 67,6\% termasuk kategori "Baik". Rekapitulasi variabel Pengelolaan Sampah 64,4\% termasuk kategori "Baik".
\end{abstract}

\section{PengantaR}

Sampah adalah sesuatu yang tidak asing lagi ditelinga, setiap mata memandang disitu ada sampah.Sampah merupakan kotoran, bias sesuatu yang tak terpakai dan buang, semua barang yang dibuang karena dianggap tidak berguna lagi, berarti dapat dikatakan sampah adalah barang bekas, barang buangan, barang tidak berguna, barang kotor dan lain-lain.

Banyaknya aktivitas dari kegiatan manusia tidak jarang menghasilkan material berupa benda sisa yang secara terus menerus akan menjadi tumpukan di alam. Benda sisa yang tidak berguna dan tidak diinginkan dalam jangka panjang akan menjadi permasalahn serius yang akan 
dilakukan pencegahan dan diberi perhatian serius. Benda sisa yang dibuang di alam tersebut biasa kita sebut sebagai sampah. Seharusnya sampah dimanfaatkan, diolah dikelolah sesuai dengan prosedur 3R Reduce (mengurangi penggunaan barang yang mengasilkan sampah), Reuse kembali barang yang bias dibuang), dan Recycle (mendaur ulang sampah).

Dalam kenyataannya, pengelolaan sampah dalam kehidupan sehari-hari tidak sesuai yang kita bayangkan.Sampah yang dijumpai dimana-mana tanpa adanya pengelolaan yang baik. Pengelolaan yang buruk mengakibatkan pencemaran baik pencemaran udara, air di dalam dan di atas permukaan , tanah, serta munculnya berbagai macam penyakit yang mengancam kesehatan masyarakat. Sampah sering menjadi barang tidak berarti bagi bagi manusia, sehingga mengakibatkan sifat acuh tak acuh terhadap keberadaan sampah.Orang sering membuang sampah sembarangan, seolah-olah mereka tidak memiliki salah apapun.Padahal membuang sampah merupakan perbuatan tidak menunjukkan kepedulian terhadap lingkungan.

Sistem pengumpulan sampah yang dilakukan oleh masyarakat kelurahan macorawalie belum baik.Hal tersebut dapat dilihat dari sampah yang dibuang oleh masyarakat kawasan tersebut dapat dilihat dari sampah organik dan non organik. (Sahil, Henie, Al, Rohman, \& Syamsuri, 2016) meningkatnya timbulan sampah tanpa sistem persampahan yang tepat diperkirakan menjadi alasan tidak terciptanya lingkungan yang bersih, disebabkan masih banyak sampah yang berhamburan di jalan dengan tidak adanya tempat fasilitas pembuangan sampah yang memadai, selain itu kebanyakan masyarakat di Kelurahan Macorawalie membuang sampah diselokan, dipinggiran sungai/jembatan, berdasarkan dari hasil wawancara dari salah satu masyarakat berinsial A yang penulis temui pada saat observasi awal mengatakan bukan hanya masyarakat Macorawalie membuang sampah tetapi ada beberapa masyarakat dari kelurahan Rappang, sehingga mengakibatkan masalah pencemaran lingkungan.

Sampah berdampak pada kesehatan, Lingkungan dan sosial ekonomi.Sampah menjadi tempat pembiakan lalat dan disenangi tikus sehingga sehingga mendorong penularan infesksi. Sampah menurunkan kualitas linkungan, estetika terganggu karna bau dan berserakan .pembuangan sampah ke badan air maka perlu adanya kesadaran masyarakat dalam hal ini karena berdampak ke masyarakat sendiri maupun lingkungan.

Sampah merupakan salah satu masalah yang hamper di dapat di setiap daerah, sampah banyak berasal dari kegiatan rumah tangga khususnya di kelurahan Macorawalie. Menurut Peraturan Daerah (PERDA) NO.7 LD.2016/TLD.2016/NO.49 tentang Pengelolaan Sampah dalam rangka meningkatkan kesehatan masyarakat dan mewujudkan kualitas lingkungan yang bersih dan sehat, perlu melakukan pengelolaan sampah secara terpadu dan komprehensif dari hulu ke hilir serta dalam rangka penanganan sampah secara komprehensif dan terpadu, perlu melibatkan peran serta masyarakat secara proposional, efektif dan efesien. Namun perlu adanya perhatian dari pemerintah setempat terkait dengan permasalahan ataupun pengelolaan sampah karena di nilai belum optimal maka kinerja pemerintah dalam hal ini masih perlu ditingkatkan demi tercapainya lingkungan yang bersih berdasarkan wawancara dengan masyarakat.

Secara umum kinerja adalah hasil kerja secara kualitas dan kuantitas yang dapat dicapai oleh seorang pegawai dalam melaksanakan tugas pokok dan fungsinya sebagai pegawai sesuai dengan tanggung-jawab yang dibebankan atau di berikan kepadanya.Kinerja pada dasarnya dapat dilihat dari dua segi, yaitu kinerja pegawai (per indvidu) dan kinerja organisasi.Kinerja pegawai adalah hasil kerja perseorangan dalam suatu organisasi. Sedangkan kinerja organisasi adalah totalitas hasil kerja yang dicapai suatu organisasi menurut Pasolong

(2010: 175)

Kinerja adalah gambaran mengenai tingkat pencapaian pelaksanaan suatu pencapaian suatu kegiatan/program/kebijakan dalam mewujudkan sasaran, tujuan, visi dan misi organisasi yang tertuang dalam perencanaan strategis suatu organisasi (Mahsun 2005). Sedangkan kinerja menurut Mahmudi (2005:6) merupakan suatu konstruk (construct) yang bersifat multidimensional, pengukurannya juga bervariasi tergantung dari kompleksitas faktor-faktor yang membentuk kinerja ( $S$. Wahyuni, 2016).

Pengelolaan sampah bisa dilihat kinerja Dinas Lingkungan Hidup belum maksimal karena masih banyak masalah sampah yang belum terlaksanakan dikarenakan kurangnya pengawan pemerintah terhadap kinerja pegawai, kurangnya disiplin kerja sehingga pegawai tidak terlalu memperdulikan apa yang menjadi kewajiban mereka dalam penanganan sampah tersebut. 
1. Kurangnya kesadaran masyarakat tentang lingkungan hidup bersih.

2. Pemerintah sudah mengsosialisasikan lingkungan hidup bersih ( Spanduk yang terpasang di jembatan ) tapi masih banyaknya masyarakat yang buang sampah bukan pada tempatnya.

3. Pemerintah belum menyediakan TPA di kelurahan Macorawalie.

Adapun masalah-masalah lain yang menjadi hambatan dalam pengelolaan sampah yaitu bias dilihat dari: bentuk kelembagaan yang tidak sesuai dengan besarnya kewenangan yang harus dikerjakan, sumber daya manusia sebagai salah satu unsur pengelolaan kurang memadai dari jumlah maupun kualifikasinya; keterbatasan dan kondisi sarana dan prasarana pengumpulan container, pengangkutan (arm roll truck) pengelolaan di tempat pembuangan akhir yang tidak optimal serta terbatasnya lahan untuk tempat pembuangan dan penanganan akhir, tidak seimbangnya pembiayaan antara besarnya biaya operasional-pemeliharaan dengan besarnya biaya penerimaan retribusi sebagai konsekuensi logis pelayanan akibat mekanisme penarikan retribusi yang kurang memadai; pengaturan dan hukum tidak maksimalnya kebijakan pengaturan pengelolaan di daerah yang mampu memberikan motivasi kesadaran peran serta masyarakayat untuk ikut secara utuh dalam pengelolaan baik menyangkut pembiayaan maupun tehnik operasional.

Karena adanya kesenjangan dengan apa yang diharapkan, berdasarkan latar belakang masalah di atas, maka peneliti berinsiatif mencoba meneliti tentang 'Kinerja Pemerintah Terhadap Pengelolaan Sampah Di Kelurahan Macorawalie Kecamatan Panca Rijang Kabupaten Sidenreng Rappang'.

\section{STUDI LITERATUR}

Kinerja merupakan indikator yang digunakan untuk mrngukur tingkat pencapaian pelaksanaan suatu program kegiatan yang tergambar melalui pencapaian sasaran, visi misi dan tujuan ornganisasi. Kinerja tersebut mempunyai kreteria dan standar tertentu yang telah ditetapkan terlebih dahulu sehingga dapat diukur dan diketahui pencapaian yang telah dilakukan oleh individu atau sekelompok orang.

Menurut Mangkunegara, (2006: 51) Kinerja adalah prestasi kerja atau hasil kerja baik kualitas maupun kuantitas yang dicapai dan dihasilakn sumber daya manusia persatuan priode waktu dalam melaksanakan tugas kerjanya sesuai dengan tanggung jawab yang diberikan kepadanya. Kinerja juga mempunyai makna yang lebih luas bukan hanya menyatakan sebagai hasil kerja, tetapi jiga bagaimana proses kerja berlangsung. Dalam hal ini kinerja adalah proses melakukan pekerjaan dengan hasil yang dicapai dalam pekerjaan tersebut. Oleh karena itu Simamora, (2004:38) menyatakan bahwa kinerja mengacu kepada kadar pencapaian tugas-tugas yang membentuk sebuah pekerjaan karyawan. Kinerja merefisikan seberapa baik karyawan memenuhi persyaratan sebuah pekerjaan.

Menurut Sedarmayanti (2001:50) Kinerja adalah terjemahan dari performance yang berarti prestasi kerja, pelaksanaan kerja, pencapaian kerja, untuk penampilan kerja. Samsudin (2005:159) Kinerja yaitu tingkat pelaksanaan tugas yang dapat dicapai seseorang, unit atau divisi dengan menggunakan kemampuan yang ada dan batasan-batasan yang telah ditetapkan untuk mencapai tujuan organisasi/perusahaan. faktor-faktor yang membetuk kinerja. Supriyono (2010:281) Kinerja adalah suatu hasil yang dicapai seseorang dalam melaksanakan tugas-tugas yang diberikan kepadanya yang didasarkan atas kecakapan, pengalaman dan kesanggupan serta waktu.

1. Kinerja

Indikator secara individu untuk mengukur kinerja (Robbins, 2006:260).

a. Kualitas

Kualitas kerja diukur dari persepsi seseorang terhadap kualitas pekerjaan yang dihasilakan serta kesempatan tugas terhadap keterampilan dan kemampuan. Menurut Kadir (2001:19) Kualitas adalah tujuan yang sulit dipahami, karena harapan para konsumen akan selalu berubah. Setiap standar baru ditemukan, maka konsumen akan menuntut lebih untuk mendapatkan standar baru lain yang lebih baru dan lebih baik. Dalam pandangan ini, kuantitas adalah proses dan bukan hasil akhir (meningkatkan kualitas kontinuitas). Adapun Indikator yang digunakan dalam kualitas yaitu: 
1) Menunjukkan fassion terhadap pekerjaannya. Seorang yang berkualitas akan menunjukkan fassion terhadap pekerjaannya meskipun posisi yang dipegangnya mungkin belum sesuai harapannya, dia akan tetap tetap bersemangat untuk bekerja.

2) Memiliki integritas tinggi Karyawan memiliki integritas tinggi akan bersikap baik didepan anda maupun dibelakang anda.

3) Berani mengambil insiatif Karyawan yang berkualitas tidak selalu bergantung pada anda atau orang lain. Menjalankan tugas dengan baik Kualitas karyawan akan dilihat dari hasil kerjanya. Karyawan yang berkualitas tahu apa saja tanggung jawab dan berusaha memberikan yang terbaik.

b. Kuantitas

Merupakan jumlah yang dihasilkan dinyatakan dalam istilah seperti jumlah unit, jumlah jumlah siklus aktivitas yang diselesaikan. Menurut Wungu dan Brotoharsojo (2003:56) bahwa "Quantity (kualitas) adalah segala bentuk satuan ukuran yang terkait dengan jumlah hasil kerja dan di nyatakan dalam ukuran angka atau yang dapat dipandankan dengan angka. Adapun indikator yang digunakan dalam kuantitas adalah:

1) Hasil kerja/jumlah kerja Hasil kerja/jumlah kerjaadalah banyaknya tugas pekerjaannya, dapat di kerjakan.

2) Penggunaan Waktu Adalah banyaknya waktu yang digunakan dalam menyelesaikan tugas dan pekerjaan.

c. Ketepatan Waktu

Merupakan tingkat aktivitas diselesaikan pada awal waktu yang dinyatakan, dilihat dari sudut koordinasi dengan hasil output serta memaksimalkan waktuyang tersedia untuk aktivitas lain. Chairil dan Ghozali (2001) adalah timeliness adalah suatu pemanfaatan informasi oleh pengambil keputusan sebelum informasi tersebut kehilangan kapasitas atas kemampuannya untuk mengambil keputusan ketepatan waktu bagi pemakai informasi sangat penting, informasi yang tepat waktu berarti jangan sampai informasi yang disampaikan sudah basi atau sudah menjadi rahasia umum. Adapun indicator yang digunakan dalam ketepatan waktu adalah Kepatuhan adalah cara kerja dengan mematuhi semua aturan yang ada.

d. Efektivitas

Merupakan tingkat penggunaan sumber daya organisasi (tenaga, uang, teknologi, bahan baku) dimaksimalkan dengan maksud menaikkan hasil dari setiap unit dalam penggunaan sumber daya. Abdurahmat mengemukakan bahwa efektivitas merupakan pemanfaatan sumber daya sarana dan prasarana dalam jumlah tertentu. Adapun indikator yang digunakan dalam efektivitas adalah :

1) Keterampilan kerja

Keterampilan menunjukkan kemampuan dan keahlian seseorang yang melaksanakan tugas.

2) Peningkatan prestasi kerja

Prestasi kerja merupakan salah satu tolak ukur yang dapat digunakan untuk menilai kinerja seseorang ataupun organisasi.

3) Kemampuan Berkompetisi

Kemampuan berkompetisi dalam dunia kerja, kompetisi merupakan salah satu hal yang penting. Kompetisi yang dimaksud dilakukan secara positif, misalnya bekerja lebih baik dari orang lain.

4) Kemampuan Beradaptasi

Adaptasi menunjukkan kemampuan seseorang menyesuaikan diri dengan situasi dan lingkungan kerja yang sering mengalami perubahan baik lingkungan kerja seperti rekan-rekan maupun sarana dan prasarana yang digunakan.

e. Kemandirian

Merupakan tingkat seseorang yang nantinya akan dapat menjalankan fungsi kerjanya. Patriana, (2007:20) menjelaskan kemandirian merupakan kemampuan individu untuk bertingkah laku secara seorang diri dan kemandirian remaja dapat dilihat dengan sikap remaja yang tepat bertdasarkan pada prinsip diri sendiri sehingga bertingkah laku sesuai keinginannya, mengambil keputusan sendiri, dan mampu 
mempertanggungjawabkan tingkah lakunya. Indikator yangdigunakan dalam kemandirian adalah :

1.) Bebas yaitu tindakan yang dilakukan sebagai dasar kehendak diri sendiri.

2.) Progresif/ulet adalah usaha untuk mengejar harapan, prestasi dengan penuh ketekunan.

3.) Insiatif adalah kemampuan untuk berfikir dan bertindak secara original, kreatif dan penuh insiatif.

\section{f. Komitmen kerja}

Merupakan suatu tingkat dimana seseorang mempunyai komitmen kerja dengan instansi dan tanggung jawab terhadap kantor. Menurut Robbins dan Judge (2008) komitmen kerja adalah suatu yang mana seorang karyawan mempunyai keinginan yang kuat untuk mempertahankan keanggotaan dalam perusahaan tersebut. Adapun indikator yang digunakan dalam komitmen kerja yaitu :

Pengalaman kerja : yaitu kemampuan di masa lampau dan cara pekerja mengutarakan dan membicarakan perasaannya tentang organisasi.

\section{Pengelolaan Sampah}

Secara umum pengelolaan merupakan kegiatan merubah sesuatu hingga menjadi baik berat memiliki nilai-nilai tinggi dari semula.Pnegelolaan dapat juga dairtikan sebagai untuk melakukan sesuatu agar lebih sesuai serta cocok dengan kebutuhan sehingga lebih bermanfaat.

Menurut Syafrudin (2001) Kinerja pengelolaan sampah sangat menentukan wajah dari suatu kota. Semakin baik sistem kinerja pengelolaan persampahan, maka semakin bersih pulakota tersebut dan sebaliknya. Nilai penting dari untuk kerja sistem pengelolaan sampah tidak saja terhadap nilai estetika kota, tetapi juga meliputi manfaat terhadap :

a. Perlindungan kesehatan masyarakat

Mengurangi tempat organisme untuk bersarang: hal ini dikarenakan jika pengelolaan sampah dilakukan dengan baik maka akan berkurangnya organisme atau hewan-hewan yang menjangkitkan penyakit seperti lalat, nyamuk dan masih banyak lainnya lagi.

b. Perlindungan terhadap pencemaran lingkungan

Tidak membuang sampah disembarang tempat: Pembuangan sampah dapat mengurangi asam organik dan gas cair organik seperti metana. Dimana gas ini jika dalam tekanan yang tinggi makaakan menyebabkan ledakan.

c. Pertumbuhan ekonomi dan kesejahteraan masyarakat

Pariwisata : Jika kinerja dalam pengelolaan sampah di suatu tempat/daerah maka akan mengundang banyak wisatawan.

d. Peningkatan nilai sosial budaya masyarakat

Pengelolaan sampah yang baik akan membentuk lingkungan yang bersih dan menyenangkan bagi semua masyarakat.

Menurut Kodoatie (2003:217) ada lima komponen-komponen yang saling mendukung satu dengan yang lain dan saling berinteraksi untuk mencapai tujuan yaitu bersih, sehat dan teratur. Adapun komponen tersebut adalah :

a. Aspek teknik Operasional (Teknik)

Teknik operasioanl pengelolaan sampah secara berantai dengan urutan yang berkesinambungan yaitu: penampungan/pewadahan, pembuangan atau pengolahan, Pengangkutan.

b. Aspek Kelembagaan (Institusi)

Organisasi manajemen yang mempunyai peran pokok diantaranya yaitu menggerakkan, mengaktifkan dan mengarahkan sistem pengelolaan sampah dengan ruang lingkup bentuk institusi,pola organisasi personalia dan manajemen.

c. Aspek Pembiayaan

Yaitu berfungsi untuk membiayai operasional pengolahan sampah dimulai dari sumber sampah/pembiayaan, pengolahan dan pembuangan akhir.

d. Aspek Peraturan 
Pengelolaan persampahan diperlukan dasar hukum pengelolaan persampahan yang mencakup (Syafruddin:2006)

1.) Peraturan daerah yang dikaitkan dengan ketentuan umum pengelolaan kebersihan yang berlaku.

2.) Peraturan daerah tentang bentukan badan pengelolaan kebersihan.

3.) Peraturan daerah yang khusus menetukan struktur tarif dan tarif dasar pengelolaan kebersihan.

e. Aspek Peran serta masyarakat

peran serta masyarakat yaitu melibatkan masyarakat dalam tindak-tindak administrator yang mempunyai pengaruh langsung terhadap mereka.

Bentuk peran serta masyarakat dalam pengelolaan sampah meliputi peran serta pasif dan peran serta aktif menurut Louise et.al dalam Irman (2004:51) diantaranya adalah:

1.) Peran serta pasif

a) Sadar akan kebersihan terhadap lingkungan seperti tidak membuang sampah di sembarang tempat dan penempatan sampah pada pewadahan yang tertutup.

b) Sadar akan kewajiban membayar retribusi. Masyarakat menyadari bahwa pengelolaan sampah memerlukan pembiayaanyang besar dan diantaranya dibebankan kepada masyarakat memalui retribusi.

2.) Peran serta aktif

a) Pengumpulan sampah dengan pola komunal

b) Kontrol social

c) Ikut dalam kegiatan gotong royong

d) Ikut serta dalam penyediaan sarana kebersihan .

\section{Faktor-faktor yang berpengaruh terhadap pengelolaan sampah:}

a) Alat perwadahan, yang biasa digunakan berupa kantong plastic dengan penempatan tempat sampah yang masih dinilai kurang mencukupi.

b) Pengumpulan, dalam hal ini upaya aparat dalam menangani sampah dengan cara mengumpulkan sampah dari sumbernya yang dianggap berpengaruh terhadap jumlah keterangkutan sampah di Kelurahan Macorawalie.

c) Pengakutan, yaitu proses atau kegiatan membawa sampah yang akan dibuang ke TPA (Tempat Pembuangan Akhir) dapat mempengaruhi jumlah keterangkutan sampah.

Kesadaran penanganan sampah individu, masyarakat diharapkan memiliki motivasi untuk bias membuang, memilah sampah dan memiliki kesadaran untuk menyediakan tempat sampah dirumah sendiri.

\section{METODE PENELITIAN}

Lokasi penelitian ini berada pada lokasi Kelurahan Macorawalie Kecamatan Panca Rijang Kabupaten Sidenreng Rappang. Alasan memilih lokasi ini karena peneliti menganggap ada kesenjangan yang tidak sesuai dengan apa yang diharapkan oleh masyarakat sebagaimana mestinya untuk perencannaan penelitian ini kurang lebih dua bulan yaitu bulan Maret dan bulan April 2020. Metode penelitian yang digunakan yaitu mengguganakan metode Kuantitatif yaitu suatu model penelitian yang bersifat induktif, objektif dan ilmiah dengan data yang diperoleh berupa angka atau pernyataan dan juga menganalisis meggunakan analisis statistik. Populasi yang digunakan dalam penelitian ini adalah keseluruhan dari masyarakat Kelurahan Macorawalie Kecamatan Panca Rijang Kabupaten Sidenreng Rappang yang berjumlah 895 Kepala Keluarga (KK). Teknik penentuan sampel yang digunakan adalah rumus Young dengan polpulasi terbilang sangat banyak atau menjadi jumlah ribuan dimasukkan untuk memperkecil jumlah pengambilan sample atau mempersempit wilayah populasi agar teknik penelitian menjadi lancar. Jika populasi berjumlah 101 sampai dengan 1000 maka persentase sample yang digunakan yaitu 10\% jadi populasi penelitian ini adalah 895 Kepala Keluarga(KK), maka 895 X $10 \%=95$.Teknik penetuan sampel yang digunakan yaitu metode porpussive sampling.Menurut Purwanto (Asra A dan Prasetyo 2013) Porpussive sampling yaitu pengambilan sampel berdasarkan keperluan peneliti artinya unit dan individu yang diambil dari populasi yang dipilih dengan sengaja berdasarkan keperluan tertentu.Sampel adalah sebagian anggota populasi yang diambil dengan menggunakan teknik sampling. Adapun kreteria yang diberikan kuesioner 
nantinya yaitu pada usia produktif yaitu umur 17 keatas (dewasa, orang tua bukan yang lanjut usia).

Non probability sampling adalah teknik pengumpulan sampel yang tidak memberikan peluang atau kesempatan sama bagi setiap unsur atau anggota populasi untuk dipilih menjadi smapel.

\section{HASIL DAN DISKUSI}

1. Kinerja

Rekapitulasi tanggapan responden tentang kinerja pemerintah

\begin{tabular}{|l|c|}
\hline Indikator Kinerja & $\begin{array}{c}\text { Persentase } \\
\mathbf{\%}\end{array}$ \\
\hline Pentingnya Kebersihan Lingkungan & $76,2 \%$ \\
\hline Meningkatkan Kinerja & $66 \%$ \\
\hline Pegawai Dalam Menjalankan Tugasnya & $69 \%$ \\
\hline Tingkat Kinerja Aparatur & $65,6 \%$ \\
\hline Waktu Yang Dimiliki Aparatur Dengan Masyarakat & $60,6 \%$ \\
\hline Kepatuhan Aparatur & $72,2 \%$ \\
\hline Keterampilan Aparatur & $62,4 \%$ \\
\hline $\begin{array}{l}\text { Aparatur dalam meningkatkan Kinerja Melalui } \\
\text { Kebersihan Lingkungan }\end{array}$ & $67 \%$ \\
\hline Bersaing Tentang Kebersihan Lingkungan & $66,4 \%$ \\
\hline $\begin{array}{l}\text { Memperingatkan Kepada Masyarakat Untuk } \\
\text { Membuang Sampah Pada Tempatnya }\end{array}$ & $75,6 \%$ \\
\hline $\begin{array}{l}\text { Aparatur Dalam Memperbaiki Kebersihan } \\
\text { Lingkungan }\end{array}$ & $69,2 \%$ \\
\hline Aparatur Dalam Meningkatkan Kinerja & $59,2 \%$ \\
\hline Tingkat Pengalaman Kerja & $69,4 \%$ \\
\hline \multicolumn{1}{|c|}{ Jumlah Rata-rata persentase 878.8/13 = 67,6\% } \\
\hline
\end{tabular}

Sumber : Rekapitulasi Kuisioner Mei 2020

Dari table diatas terdapat tiga belas indikator dalam kinerja pemerintah yang digunakan penelitiuntuk mengukur bagaimana kinerja pemerintah di Kelurahan Macorawalie Kecamatan Panca Rijang Kabupaten Sidenreng Rappang. Adapun indikator pertama adalah pentingnya kebersihan lingkungan dari hasil persentase diperoleh 76,2\% termasuk kategori baik, indikator kedua meningkatkan kinerjanya dari hasil persentase diperoleh $66 \%$ termasuk kategori baik, indikator ketiga adalah kemampuan pegawai dalam menjalankan tugasnyadari hasil persentase diperoleh69\% termasuk kategori baik, indiktor keemepat adalah tingkat kinerja aparatur dari hasil persentase diperoleh65,6\% termasuk kategori baik, indikator kelima adalah waktu yang di miliki aparatur dengan masyarakat dari hasil persentase diperoleh 60,6\% termasuk kategori baik, indikator keenam adalah kepatuhan aparaturdari hasil persentase diperoleh72,2\% termasuk kategori baik, indikator ketujuh adalah keterampilan aparatur dari hasil persentase diperoleh62,4\% termasuk kategori baik, indikator kedelapan adalah aparatur dalam meningkatkan kinerja melalui kebersihan lingkungan dari hasil persentase diperoleh67\% termasuk kategori baik, indikator kesembilan adalah kemampuan pegawai dengan masyarakat untuk bersaing dari hasil persentase diperoleh66,4\% termasuk kategori baik, indikator kesepuluh adalah aparatur pemerintah dalam memperingatkan kepada masyarakat untuk membuang sampah pada tempatnya dari hasil persentase diperoleh75,6\% termasuk kategori baik, Indikator kesebelas adalah aparatur dalam memperbaiki kebersihan lingkungan dari hasil persentase diperoleh69,2\% termasuk kategori baik, indikator keduabelas adalah kemampuan aparatur untuk meningkatkan kinerja dari hasil persentase diperoleh59,2\% termasuk kategori tidak baik, indicator ketigabelas adalah tingkat pengalaman kerja yang dimiliki aparatur tentang 
pengelolaan sampah dari hasil persentase diperoleh69,4\% termasuk kategori baik, hasil akumulasi rekapitulasi mengenai kinerja pemerintah di Kelurahan Macorawalie Kecamatan Panca Rijang Kabupaten Sidenreng Rappang dengan rata-rata persentase 67,6\% atau dikategorikan baik.

\section{Pengelolaan Sampah}

Rekapitulasi tanggapan responden tentang pengelolaan sampah.

\begin{tabular}{|l|l|}
\hline Indikator Pengelolaan sampah & Persentase( \\
\hline Mengontrol Pertumbuhan Sampah & $60,4 \%$ \\
\hline Menyediakan Tempat Penampungan Sampah & $59,2 \%$ \\
\hline Badan Pengelolaan Sampah & $66,6 \%$ \\
\hline Fungsi Aparat Dalam Mengelolah Sampah & $65,4 \%$ \\
\hline Membiayai Operasional Pengelolaan Sampah & $62,8 \%$ \\
\hline Biaya Operasional Dan Pemeliharaan & $59,4 \%$ \\
\hline Peraturan Daerah Yang Berlaku & $74,6 \%$ \\
\hline Ketegasan Aparat Dalam Meberikan Sanksi & $65 \%$ \\
\hline $\begin{array}{l}\text { Keterlibatan Masyarakat Dalam Pengelolaan } \\
\text { Sampah }\end{array}$ & $62 \%$ \\
\hline Keikutsertaan Masyarakaat & $67,4 \%$ \\
\hline $\begin{array}{l}\text { Jumlah 642.8\% } \\
\text { Rata-Rata Persentase 642.8/10 }=64,2 \%\end{array}$ \\
\hline
\end{tabular}

\section{Sumber : Oleh Data Primer, Mei 2020}

Tabel diatas terdapat sepuluh indikator pengelolaan sampah yang digunakan oleh peneliti untuk mengukur bagaimana pengelolaan sampah di Kelurahan Macorawalie Kecamatan Panca Rijang Kabupaten sidenreng Rappang. Adapun indikator yang pertama adalah upaya aparat dalam mengontrol pertumbuhan sampah dengan persentase 60,4\% termasuk kategori baik, indikator kedua adalah kemampuan aparat untuk mneyediakan tempat penampungan sampah yang memadai dengan persentase $59,2 \%$ termasuk kategori tidak baik, indikator ketiga adalah struktur organisasi dari badan pengelola persampahan dengan persentase $66,6 \%$ termasuk kategori baik, indikator keempat adalah fungsi aparat dalam mengelolah sampah dengan persentase 65,4\% termasuk kategori baik, indikator kelima adalah membiayai operasional pengelolaan sampah dengan persentase $62,8 \%$ termasuk kategori baik, indikator keenam adalah biaya operasional dan pemeliharaan dengan persentase 59,4\% termasuk kategori tidak baik, indikator ketujuh adalah pengelolaan persampahan sesuai dengan peraturan daerah yang berlaku dengan persentase $74,6 \%$, indikator kedelapan adalah ketegasan aparat dalam memberikan sanksi dengan persentase 65\% termasuk kategori baik, indikator kesembilan adalah keterlibatan masyarakat dalam pengelolaan sampah dengan persentase $62 \%$ termasuk baik, indikator kesepuluh adalah keikutsertaan masyarakat dalam kegiatan pengelolaan sampah dengan persentase 67,4\% termasuk kategori baik, hasil akumulasi rekapitulasi pengelolaan sampah di kelurahan Macorawalie Kecamatan Panca Rijang Kabupaten Sidenreng Rappang adalah dengan rata-rata persentase 64,2\% atau dikategorikan baik.

\section{Analisis Tabel Summary}

\section{Model Summaryb}

\begin{tabular}{|c|c|c|c|c|}
\hline odel & & $\begin{array}{r}\mathrm{R} \\
\text { Square }\end{array}$ & \begin{tabular}{|lr}
\multicolumn{2}{r}{ Adj } \\
usted \\
Square \\
\end{tabular} & $\begin{array}{l}\text { Std. Error } \\
\text { of the Estimate }\end{array}$ \\
\hline & $525^{\mathrm{a}}$ & 6 & 8 & 5.429 \\
\hline
\end{tabular}




\section{Pemerintah}

a. Predictors: (Constant), Kinerja

b. Dependent Variable: Pengelolaan Sampah

Sumber : Hasil Olah Data SPSS 16.0

Hal ini diperkuat dengan hasil data Model Summary, dimana nilai R Square 0,276 berarti secara bersama $1.5 \%$ perubahan variabel kinerja pemerintah (Y) dapat dijelaskan oleh pengelolaan sampah (X), atau dengan kata lain pengaruh variabel bebas terhadap variabel terikat sebesar $1.5 \%$ sedangkan sisanya $98.5 \%$ dipengaruhi oleh faktor lain yang tidak masuk dalam kerangka penelitian ini.

\section{KESIMPULAN}

Berdasarkan penelitian selama kurang lebih dua bulan maka peneliti menarik kesimpulan untuk menjawab pertanyaan rumusan masalah penelitian. Beberapa kesimpulan yang dapat ditarik dari penelitian ini yaitu sebagai berikut:

1. Kinerja pemerintah di Kelurahan Macorawalie Kecamatan Panca Rijang Kabupaten Sidenreng Rappang, dilihat dari pentingnya kebersihan lingkungan,meningkatkan kinerja,pegawai dalam menjalankan tugasnya,tingkat kinerja aparatur, waktu yang dimiliki aparatur dengan masyarakat, kepatuhan aparatur, keterampilan aparatur, meningkatkan kinerja melalui kebersihan lingkungan, bersaing tentan kebersihan lingkungan, memperingatkan kepada masyarakat untuk membuang sampah pada tempatnya, aparatur dalam memperbaiki kebersihan lingkungan, aparatur dalam meningkatkan kinerja, tingkat pengalaman kerja, dengan persentase $67,6 \%$ masih pada kategori baik, meskipun demikian pencapaian indikator belum mencakup sepenuhnya sesuai apa yang diharapkan. Sedangkan dari pengelolaan sampah dilihat dari mengontrol pertumbuhan sampah, menyediakan tempat penampungan sampah, badan pengelolaan sampah, fungsi aparat dalam mengelolah sampah, membiayai operasional sampah, biaya operasional dan pemeliharaan, peraturan daerah yang berlak, ketegasan aparat dalam memberikan sanksi, keterlibatan masyarakat dalam pengelolaan sampah, keikutsertaan masyarakat, dengan persentase $64,2 \%$ masi pada kategori baik, meskipun demikian pencapaian indikator belum mencakup sepenuhnya sesuai apa yang diharapkan.

2. Faktor-faktor yang berpengaruh terhadap kinerja pengelolaan sampah adalah:

a. Alat perwadahan, yang biasa digunakan berupa kantong plastik dengan penempatan tempat sampah yang masih dinilai kurang mencukupi.

b. Pengumpulan, dalam hal ini upaya aparat dalam menangani sampah dengan cara mengumpulkan sampah dari sumbernya yang dianggap berpengaruh terhadap jumlah keterangkutan sampah dikelurahan Macorawalie.

c. Pengangkutan yaitu proses atau kegiatan membawa sampah yang akan dibuang ke TPA (Tempat Pembuangan Akhir) dapat mempengaruhi jumlah keterangkutan sampah.

d. Kesadaran Penanganan Sampah Individu, masyarakat diharapkan memiliki kesadaran utuk menyediakan tempat sampah dirumah sendiri.

Kinerja pemerintah terhadap pengelolaan sampah di Kelurahan Macorawalie Kecamatan Panca Rijang Kabupaten Sidenreng Rappang dinyatakan berpengaruh signifikansi dengan nilai $t_{\text {hitung }} \geq t_{\text {tabel, }}$ yaitu dengan jumlah $1,692 \geq 1.661$.. 


\section{REFERENSI}

Ahmad Jamaluddin, S. M. (2015). Metode Penelitian Administrasi Publik Teori Dan Aplikasi. Yogyakarta: Gava Media.

Dr. Sanusi Hamid, S. M. (2014). Manajemen Sumber Daya Lanjutan. Jl. Elang 6, No3, Drono, Sardonoharjo, Ngaglik, Sleman: Cv Budi Utama.

Drs. Bintoro, M. T. (2017). Manajemen Penilaian Kinerja Karyawan. Yogyakarta: Gava Media.

Rahadi, D. D. (2010). Manajemen Kinerja Sumber Daya Manusia. Jln. Taman Kebun Raya A-1 No. 9 Pakis Malang :P Tunggal Mandiri Publishing.

Sulaksono, H. (2015). Budaya Organisasi Dan Kinerja. Jl. Rajawali, G. Elang 6, No 3, Drono, Sardonoharjo, Ngaglik, Sleman: Cv Budi Utama.

Zainuddin, B. M. (2017). Teori-teori Mutakhir Dalam Perspektif Ilmu Admninistrasi Publik. Makassar: Phinisi Utama Media.

Andree Wijaya. (2015). Pengaruh Kemampuan Dan Motivasi Terhadap Kinerja Karyawan The Effect Of Ability And Motivation On E mployee's Performance. Jurnal Ekonomi, 1(2015), 1-17. https://doi.org/10.2217/nnm.12.92

Damayanti, R., Hanafi, A., \& Cahyadi, A. (2018). Pengaruh Kepuasan Kerja Terhadap Kinerja Karyawan (Studi Kasus Karyawan Non Medis Rs Islam Siti Khadijah Palembang) Riski Damayanti 1, Agustina Hanafi 2 , \& Afriyadi Cahyadi 3. L Ilmiah Manajemen Bisnis Dan Terapan Tahun, (2), 75-86.

Faizah. (2008). Berbasis Masyarakat (Studi Kasus Di Kota Yogyakarta) Berbasis Masyarakat.

Hartanto, W. (2006). Kinerja Pengelolaan Sampah di Kota Gombong Kabupaten Kebumen. Universitas Diponegoro.

Leluno, T., Soedarsono, \& Wibowo, K. (n.d.). Analisa Kinerja Pengelolaan Persampahan. 210-220.

Nigiana, J. (2013). Manajemen Pengelolaan. 1(4), 53.

Rahardjo, M. (2014). Faktor-Faktor Yang Mempengaruhi Kinerja Pengelolaan Sampah Di Pasar Banjarsari Kota Pekalongan. 2, 192-199.

Wahyudi, A. (2016). Analisis kebijakan pengelolaan sampah di kota samarinda: problematisasi kebijakan dengan pendekatan wpr. 12(2), 91-106.

Wahyuni, E. S., \& Rosmida, R. (2016). ANALISIS KINERJA APARAT PEMERINTAH DAERAH (Studi Empiris Pada Pemerintah Kabupaten Bengkalis). Inovbiz: Jurnal Inovasi Bisnis, 4(2), 99. https://doi.org/10.35314/inovbiz.v4i2.74

Wahyuni, S. (2016). Kinerja Dinas Lingkungan Hidup Dalam Pengelolaan Sampah Di Kota Manado.

Peraturan Daerah (PERDA) N0.7 LD.2016/TLD.2016/N0.49Tentang Pengelolaan Sampah

Undang-undang Nomor 18 tahun 2008 tentang Pengelolaan Sampah. 